\section{Arrivoc

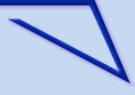

Archive for

Organic Chemistry
The Free Internet Journal

for Organic Chemistry
Paper

Arkivoc 2019, v, 0-0

\title{
Synthesis and photochromism of naphtho[2,1-b]furyl fulgides
}

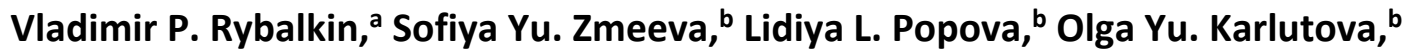

Alexander D. Dubonosov, ${ }^{\text {*a }}$ Vladimir A. Bren, ${ }^{b}$ and Vladimir I. Minkin ${ }^{b}$

${ }^{a}$ Federal Research Centre the Southern Scientific Centre of the Russian Academy of Sciences, 344006 Rostov on Don, Russian Federation

${ }^{b}$ Institute of Physical and Organic Chemistry, Southern Federal University, 344090 Rostov on Don, Russian Federation

E-mail: aled@ipoc.sfedu.ru

Received 05-17-2019

Accepted 06-15-2019

Published on line 07-03-2019

\section{Abstract}

A series of novel 2- and 5-naphtho[2,1-b]furyl fulgides with different combinations of substituents $(\mathrm{H}, \mathrm{Me}, \mathrm{Et})$ in the furan ring and methylidene bridge were synthesized and their spectral, luminescent and photochromic properties were studied. The most sterically overcrowded ring-opened fulgides $4 Z O$ and $14 Z O$ under UV irradiation rearrange into the colored fluorescent ring-closed isomers $\mathbf{C}$. The reverse dark reaction $\mathbf{C} \rightarrow E \mathbf{O}$ is not observed at room temperature over $48 \mathrm{~h}$. The exposure of $\mathbf{C}$ forms to visible light results in the backward isomerization into the initial non-fluorescent form $\mathbf{0}$. Thus, fulgides $\mathbf{4}$ and $\mathbf{1 4}$ represent photochromic compounds with modulated fluorescence which are sufficiently fatigue-resistant with respect to photodegradation, surviving at least ten cycles of photocoloration-photobleaching without notable decrease in the optical density at the absorption maximum of the cyclic form $\mathbf{C}$.

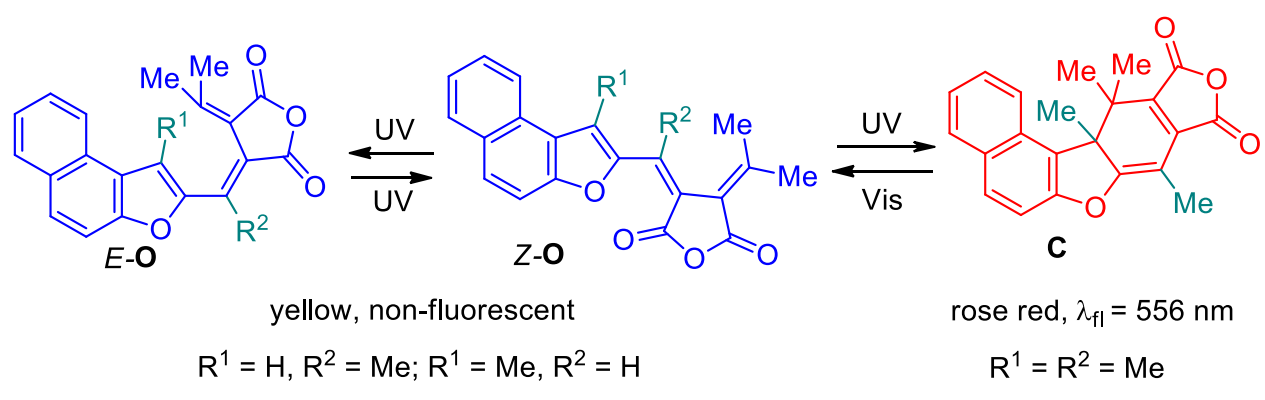

Keywords: Fulgides, naphtho[2,1-b]furan, photochromism, isomerization, fluorescence 


\section{Introduction}

Bistable photochromic compounds capable of reversible transformation between two isomeric forms serve as basic elements of new polyfunctional materials for molecular electronics, optical molecular memory, molecular logic devices and switches, light-driven liquid crystalline materials, photo-pharmacology, biological data visualization, and chemo- and biosensors. ${ }^{1-9}$ Heterocyclic fulgides are widely studied in this regard due to their high thermal stability and the fatigue resistance of their photocolored cyclic forms. Photoirradiation of these compounds results in the electrocyclic hexatriene-cyclohexadiene rearrangement of ring-opened isomers $\mathbf{O}$ into colored ring-closed isomers $\mathbf{C}$. The isomeric forms $\mathbf{O}$ and $\mathbf{C}$ possessing markedly different physical chemical characteristics do not interconvert when irradiation ceases. Of particular interest are fulgides exhibiting fluorescent properties of one or both isomeric forms that is mandatory in design of high capacity 3D multilayer memory systems. ${ }^{10-12}$ Previously, we synthesized and studied spectral-luminescent and photochromic properties of 1-benzofuryl and naphtho[1,2-b]furyl fulgides. ${ }^{13,14}$ Taking into account that spectral and fatigue resistance characteristics of this class of photochromic compounds are considerably dependent on the nature of their heterocyclic moieties, ${ }^{11,15}$ we have synthesized novel naphtho[2,1-b]furyl fulgides and studied their properties in comparison with their $[1,2-b]$ analogues.

\section{Results and Discussion}

Fulgides $4 Z$ and $5 E$ were synthesized starting from 1-methylnaphtho[2,1-b]furan 1 according to Scheme 1. Acetylation and formylation of 1 led to 2-acetyl-1-methylnaphtho[2,1-b]furan 2 and 1-methylnaphtho[2,1-b]furan-2-carbaldehyde 3, respectively. The trienes $4 Z$ and $5 E$ were prepared by Stobbe condensation of 2 and 3, correspondingly, with diethyl isopropylidenesuccinate in THF followed by hydrolysis and cyclization. The intermediate mono ethyl esters $4 \mathrm{M}, 5 \mathrm{M}$ and the corresponding fulgenic acids $4 \mathrm{~F}, 5 \mathrm{~F}$ were purified and used in the next step of the reaction without isolation. The $\mathbf{5 Z}$-isomer was obtained from $\mathbf{5} E$ according to a specially developed technique based on differential solubilities of $Z$ and $E$ forms in benzene coupled with the use of irradiation (see Experimental Section).

2-Naphtho[2,1-b]furyl 11 and 5-naphtho[2,1-b]furyl fulgides 13, 14 were synthesized as shown in Scheme 2. 2-Acetylnaphtho[2,1-b]furan 6 under the Stobbe condensation conditions gave rise to fulgide $11 E$ and to side product 12, which is rather unusual for this reaction. Here, one of the methyl groups of the isopropylidene fragment was involved in the condensation. The 11Z-Isomer was obtained from $11 E$ according to the technique based on different solubility of $Z$ and $E$ forms in acetonitrile and irradiation of the $E$ form as in the $\mathbf{5} E \rightarrow \mathbf{5 Z}$ conversion (see Experimental Section).

The Vilsmeier-Haack formylation of 2-ethylnaphtho[2,1-b]furan $\mathbf{7}$ led to the 5-formyl product 8 as a single product, while the Friedel-Crafts acetylation of 7 generated a mixture of 1-acetyl- 9 and 5-acetyl-2ethylnaphtho[2,1-b]furan $\mathbf{1 0}$ as the dominant product. It should be mentioned that the last result is in disaccord with the data ${ }^{16}$ that reported the exclusive formation of the product of 2-acylation. The Stobbe condensation of $\mathbf{8}$ and $\mathbf{1 0}$ with diethyl isopropylidenesuccinate in THF followed by hydrolysis and cyclization gave rise to fulgides $13 E$ and $14 Z$, respectively. Intermediate mono ethyl esters $11 \mathrm{M}, 13 \mathrm{M}, 14 \mathrm{M}$ and the corresponding fulgenic acids 11F, 13F, 14F were purified and involved in the next step of the reaction without isolation. 


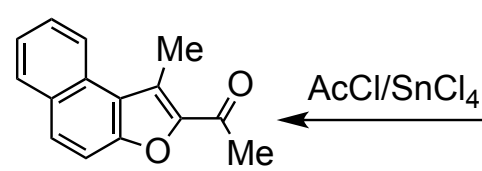

2<smiles>CCOC(O)C(C)(C)C(OCC)OCC</smiles><smiles>CCOC(=O)/C(C(=O)O)=C(\C)c1oc2ccc3ccccc3c2c1C</smiles><smiles>CC(C)=C(C(=O)O)C(C(=O)O)=C(C)c1oc2ccc3ccccc3c2c1C(C)C(O)CC(C)(F)F</smiles><smiles>CCOC(C)CCOc1cc2c3ccccc(c1-3)C=CO2</smiles><smiles>Cc1oc2ccc3ccccc3c2c1C</smiles>

1<smiles>Cc1c(C=O)oc2ccc3ccccc3c12</smiles>

3<smiles>CCOC(OCC)C(C)(C)C(OCC)OCC</smiles><smiles>CCOC(=O)/C(=C/c1oc2ccc3ccccc3c2c1C)C(C(=O)O)=C(C)C</smiles><smiles>COC(=O)C(C(=O)O)=C(C=Cc1oc2ccc3ccccc3c2c1C)C(=O)O</smiles>

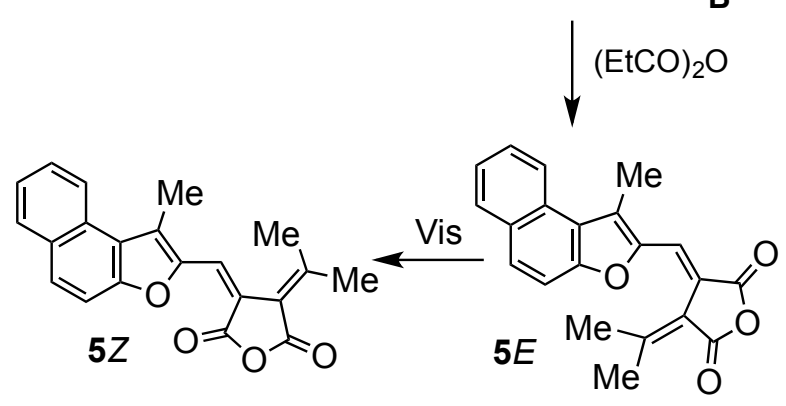

Scheme 1. Synthesis of 2-(1-methylnaphtho[2,1-b]furyl) fulgides $4 Z, 5 Z$ and $5 E$.

The structures of the ring-opened $Z$ - and $E$-isomeric forms $O$ of fulgides 4, 5, 11, 13 and 14 were confirmed by ${ }^{1} \mathrm{H}$ and ${ }^{13} \mathrm{C}$ NMR and IR spectrometry. The IR spectra of these compounds exhibit characteristic spectral bands of two exocyclic furandione carbonyl groups at $1744-1823 \mathrm{~cm}^{-1}$. The ${ }^{1} \mathrm{H}$ NMR spectra of $5 E, 11 E$ and $13 E$ contain signals of methyl group protons at 1.33-1.95 and 2.40-2.80 ppm, unambiguously indicative of their Zconfiguration. ${ }^{17}$ Analogues signals of $4 Z, 5 Z, 11 Z$ and $14 Z$ are observed at 2.01-2.73 ppm.

The electronic absorption spectra of fulgides 4, 5, 11 and 13 in toluene are characterized by long wavelength bands with maxima in the range of 403-431 nm (Table 1). Compound 14 absorbs in a somewhat shorter-wave region of the spectrum. Table 1 also contains data on the absorption spectrum of the $E$ form of isopropylidene-4-[1-(5-methoxy-2-methylnaphtho[1,2-b]furan-3-yl)ethylidene]dihydrofuran-2,5-dione $15 .{ }^{14}$ From these data, it follows that naphtho[1,2-b]furan-based fulgide absorbs in the shorter wavelength region of the spectrum and has a lower molar extinction coefficient in comparison with naphtho[2,1-b]furan-based analogues. Both $Z$ and $E$ forms of all the prepared fulgides do not have fluorescent properties. 


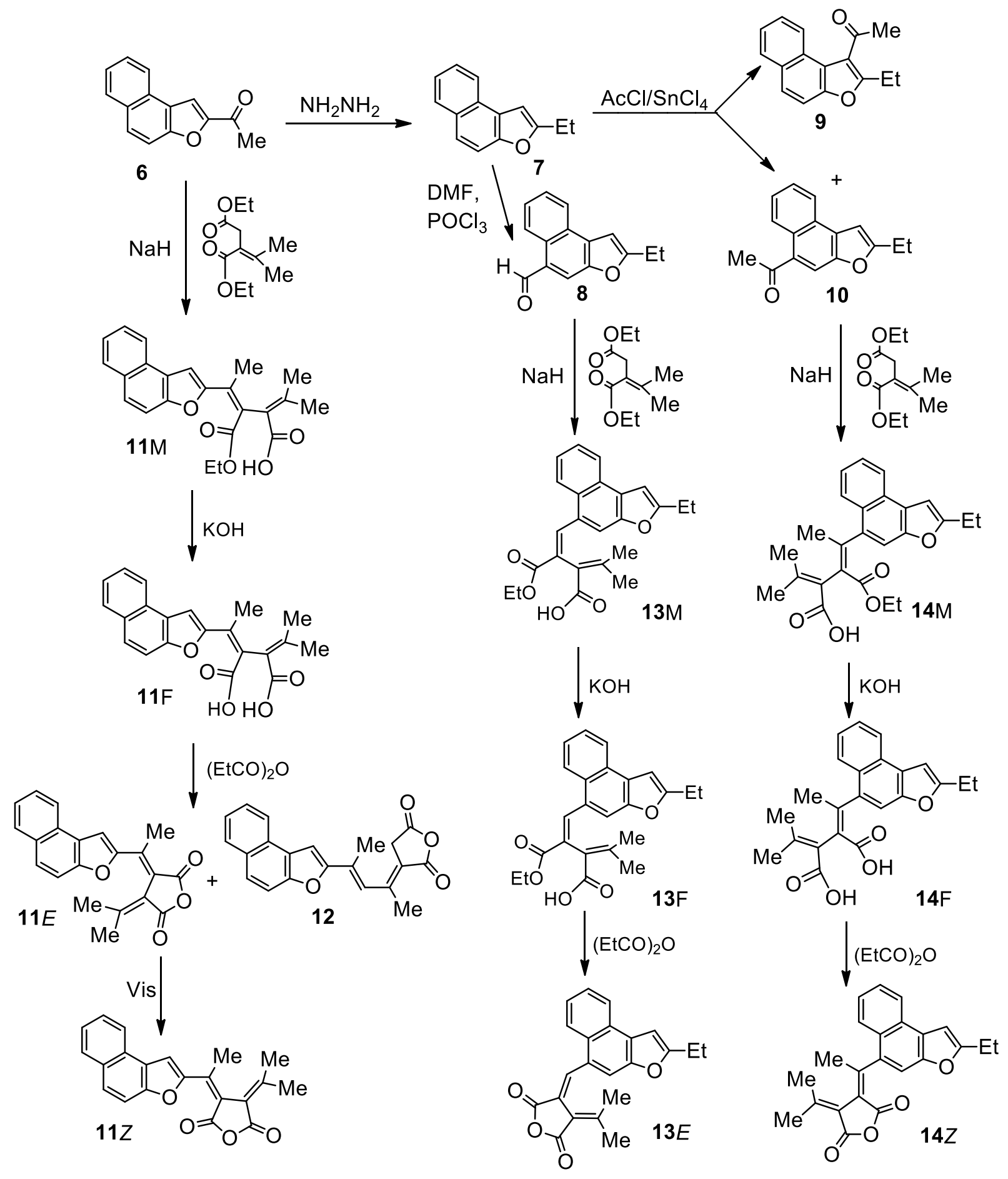

Scheme 2. Synthesis of 2-(naphtho[2,1-b]furyl) $11 E, 11 Z, 12$ and 5-(naphtho[2,1-b]furyl) containing compounds $13 E, 14 Z$.

Irradiation of toluene solutions of fulgides $5 E, 11 E$ and $13 E$ with light of $365 \mathrm{~nm}$ leads to the spectral changes characteristic of $E / Z$-isomerization processes ${ }^{18,19}$ not followed by the formation of the ring-closed forms $\mathbf{C}$, known to absorb in the visible region ${ }^{20}$ (Scheme 3, Fig. 1). In all cases, a slight bathochromic shift of 5$8 \mathrm{~nm}$ accompanied by a moderate hyperchromic effect was detected. The reversible transformations are initiated by exposure to light of $436 \mathrm{~nm}$. 
Table 1. Electronic absorption spectra of the isomeric forms of fulgides 4, 5, 11, 13-15 in toluene

\begin{tabular}{cllll}
\hline & \multicolumn{4}{c}{ Ring-opened form O } \\
\cline { 2 - 5 } Compound & \multicolumn{2}{c}{ Z-isomer } & \multicolumn{3}{c}{ E-isomer } \\
\cline { 2 - 5 } & $\lambda_{\max }, \mathrm{nm}$ & $\varepsilon_{\max }, \mathrm{L} \mathrm{mol}^{-1} \mathrm{~cm}^{-1}$ & $\lambda_{\max }, \mathrm{nm}$ & $\varepsilon_{\max }, \mathrm{L} \mathrm{mol}^{-1} \mathrm{~cm}^{-1}$ \\
\hline $\mathbf{4}$ & 404 & 19600 & 401 & 15900 \\
$\mathbf{5}$ & 431 & 18800 & 423 & 14400 \\
11 & 415 & 18100 & 407 & 15500 \\
13 & - & - & 403 & 18300 \\
14 & $330,365 \mathrm{sh}$ & 19400,8000 & 330,356 & 16500,14200 \\
15 & - & - & 344 & 10100 \\
\hline
\end{tabular}
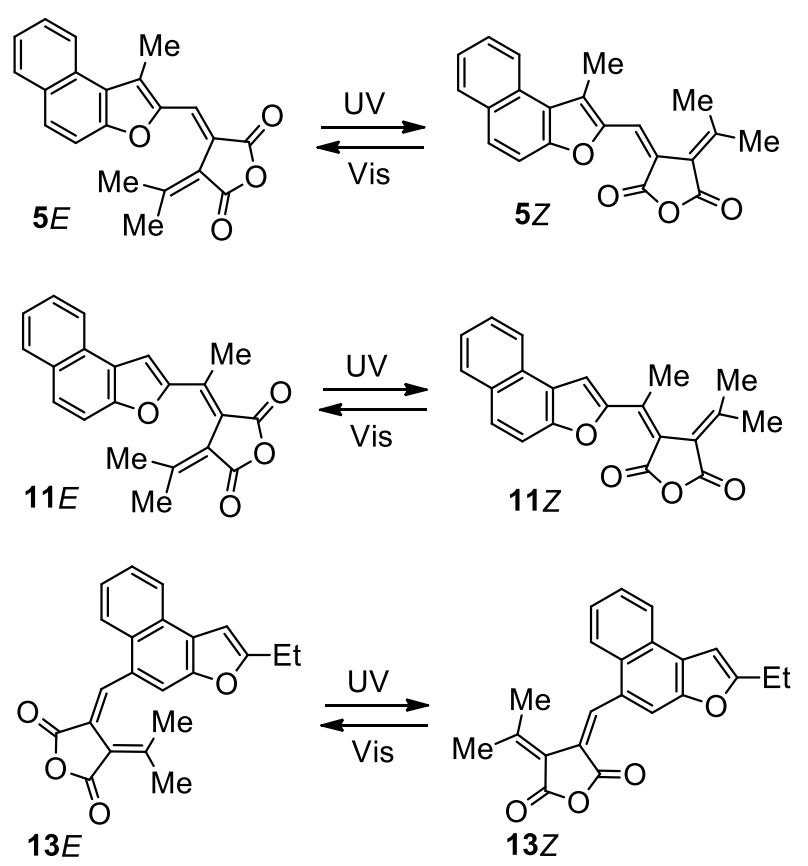

Scheme 3. E/Z-Isomerization of $5 E, 11 E$ and $13 E$ under irradiation with light of $365 \mathrm{~nm}$

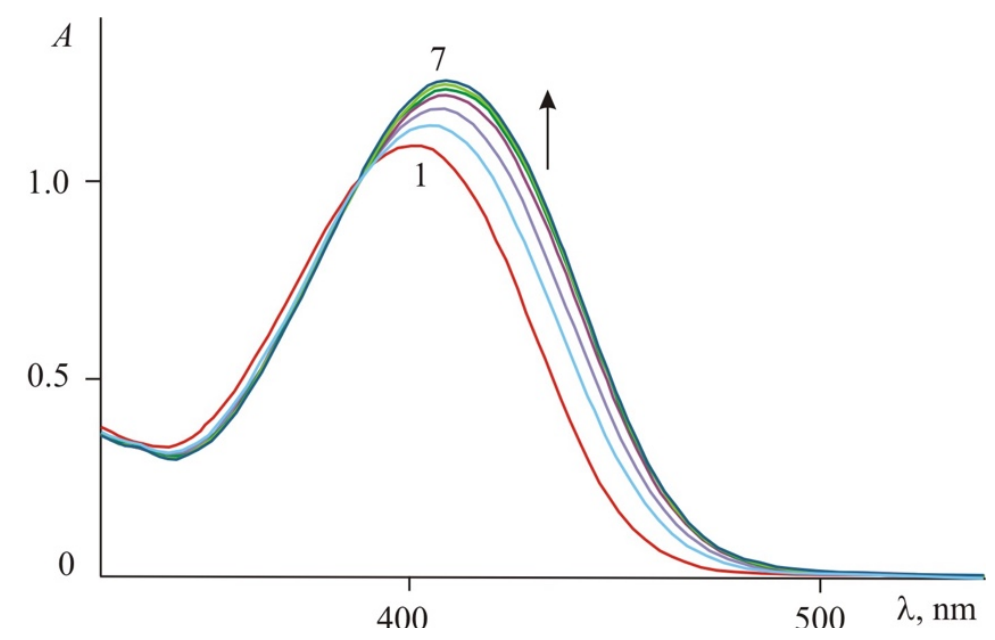

Figure 1. Electronic absorption spectra of fulgide $13 E$ in toluene before (1) and after irradiation with UV-light (365 nm) for 0.5 (2), 1 (3), 2(4), 5(5), 10(6) and 15 (7) $\min \left(6.0 \cdot 10^{-5} \mathrm{M}\right)$. 
Similarly, irradiation of toluene solutions of $5 Z$ and $11 Z$ with UV-light resulted in only Z/E-isomerization without formation of the ring-closed forms $\mathbf{C}$. However, irradiation of the most sterically overcrowded fulgides $4 Z$ and $14 Z$ in toluene with light of $365 \mathrm{~nm}$ led to a rose red photocoloration of the solution due to the appearance of a new absorption band with a maximum at $480 \mathrm{~nm}$, the intensity of which increased upon irradiation while the intensity of the initial long wavelength absorption band decreased (Fig. 2, Table 2). These spectral changes are indicative of the occurrence of the electrocyclic rearrangement of hexatriene ringopened isomer $\mathbf{O}$ into 1,3-cyclohexadiene ring-closed form $\mathbf{C}$ that involves a prior $\mathbf{Z} / \mathbf{E}$-isomerization step of $\mathbf{O}$ (Scheme 4) and results in the formation of the photostationary state. ${ }^{1,11,19}$ The establishment of the photostationary state is caused by the substantial overlap of the absorption bands related to the $S_{0} \rightarrow S_{1}$ transition of the initial ring-opened form $\mathbf{O}$ and the $S_{0} \rightarrow S_{2}$ transition of the photoinduced isomer $\mathbf{C}^{11,15}$ It should be mentioned that the ring-closed form $\mathbf{C}$ of naphtho[1,2-b]furan-based fulgide 15 absorbs in the longer wavelength region of the spectrum in comparison with naphtho[2,1-b]furan-based compounds.

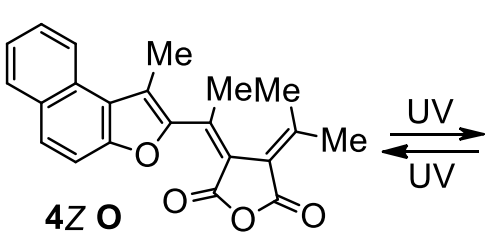

$4 Z 0$<smiles>CCO[14C](=O)[O-]</smiles>

$14 Z 0$

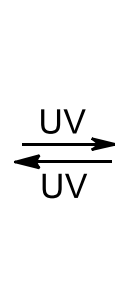

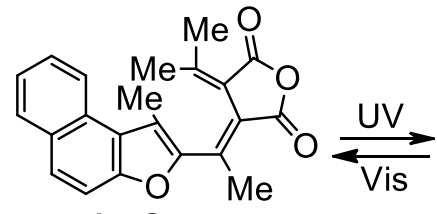

$4 E 0$<smiles>C=C1C(=O)OC(=O)C1=C(C)c1cc2oc(CC)cc2c2ccccc12</smiles><smiles>CC1=C2Oc3c(C)cc4ccccc4c3C2(C)C(C)(C)C2=C1C(=O)OC2=O</smiles>

$4 \mathrm{C}$

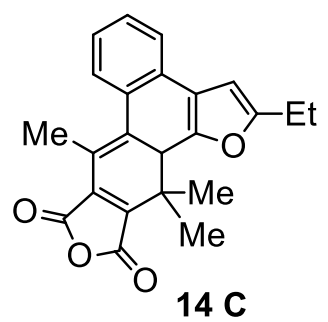

Scheme 4. Photosomerization of fulgides $4 Z$ and $14 Z$.

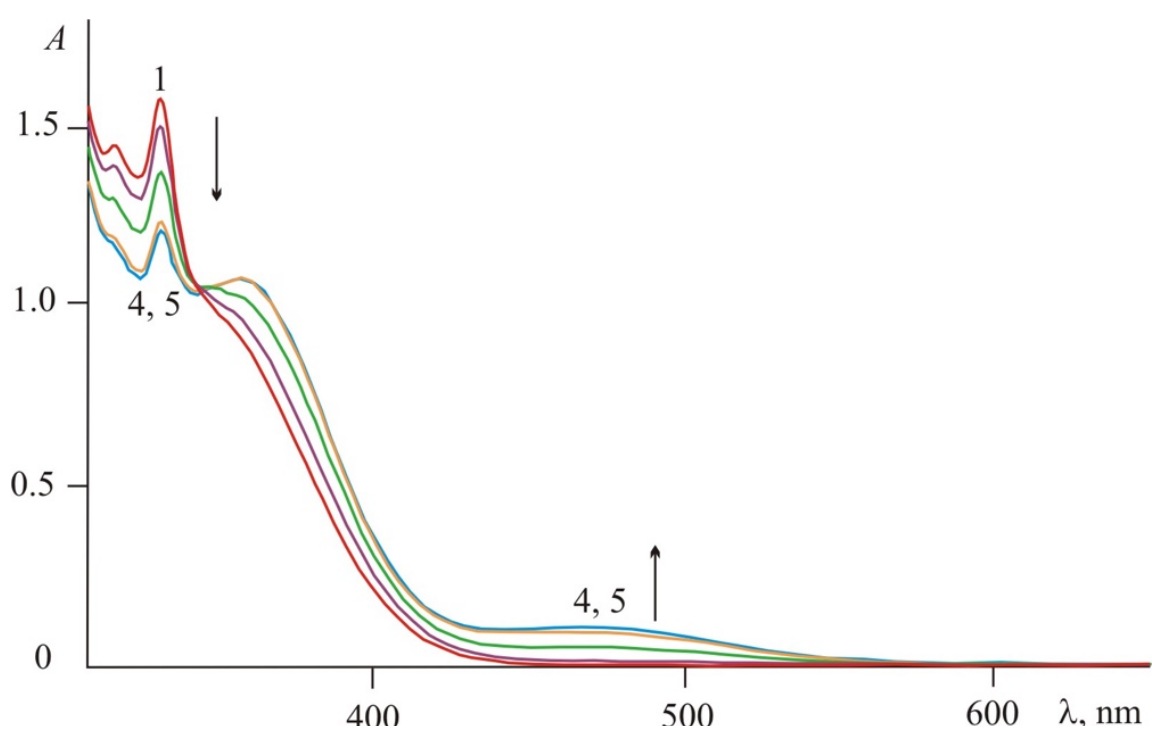

Figure 2. Electronic absorption spectra of fulgide $14 Z$ in toluene before (1) and after irradiation with UV-light (365 nm) for $15 \mathrm{~s}(2), 2(3), 15(4)$ and $30 \mathrm{~min}(5)\left(1.0 \cdot 10^{-5} \mathrm{M}\right)$. 
Table 2. Absorption and fluorescent spectra of fulgides $\mathbf{4}$ and $\mathbf{1 4}$ in toluene

\begin{tabular}{|c|c|c|c|c|}
\hline \multirow{3}{*}{ Compound } & \multicolumn{4}{|c|}{ Ring-closed form $\mathbf{C}$} \\
\hline & \multicolumn{2}{|c|}{ Absorption } & \multicolumn{2}{|c|}{ Fluorescence } \\
\hline & $\lambda_{\max }, \mathrm{nm}$ & $A^{a}$ & $\lambda_{\mathrm{fl}}, \mathrm{nm}$ & I, a.u. \\
\hline 4 & 477 & 0.05 & 556 & 110 \\
\hline 14 & 469 & 0.14 & 560 & 140 \\
\hline 15 & 546 & 0.15 & 648 & 170 \\
\hline
\end{tabular}

${ }^{a} A$ - optical density (for $I=1 \mathrm{~cm}$ ) of the colored isomer in the photostationary state upon irradiation with $365 \mathrm{~nm}$ light

No changes in the absorption maxima of photoinduced isomers 4 C, 14 C were found at room temperature after three days in dark conditions, which indicates the absence of backward thermal processes and a high thermal stability of the ring-closed isomers of these fulgides. However, subsequent irradiation of the colored solutions of 4 C, $14 \mathrm{C}$ with light of $436 \mathrm{~nm}$ leads to their photodecoloration due to the reverse ring-opening photoreaction $\mathbf{C} \rightarrow E / Z-0 .{ }^{11,15}$

Ring-closed forms of fulgides 4 C, 14 C display fluorescence in solution in toluene (Table 1). The fluorescence excitation spectra are in good agreement with the long-wavelength absorption of $\mathbf{C}$ isomers, which confirms that only ring-closed isomers $\mathbf{C}$ are responsible for the observed emission properties. After photodecoloration of $\mathbf{1 a - c}$ the intensity of fluorescence decreases to zero. Fulgides $\mathbf{4}$ and $\mathbf{1 4}$ are capable of modulation of the emission by UV/visible light at least for 10 cycles without change of absorption and fluorescence intensities.

\section{Conclusions}

In conclusion, novel 2- and 5-naphtho[2,1-b]furyl fulgides with different combinations of substituents $(H, M e$, $\mathrm{Et}$ ) in the furan ring and methylidene bridge were synthesized. Irradiation of fulgides $5 E, \mathbf{1 1} E, \mathbf{1 3 E}$ and $5 Z, 11 Z$ with UV-light resulted in $E / Z$ (Z/E)-isomerization processes without formation of the ring-closed forms $\mathbf{C}$. On the contrary, the most sterically overcrowded fulgides 4 and $\mathbf{1 4}$ behave as photochromic compounds with modulated fluorescence and possess high resistance to photocoloration-photobleaching cycling. UVirradiation of their ring-opened isomers $\mathbf{O}$ induces the rearrangement into thermally stable rose red ringclosed forms $\mathbf{C}$ exhibiting fluorescence properties in contrast to the initial $\mathbf{O}$ structures. The irradiation of ringclosed isomeric forms with visible light leads to their re-opening and complete fluorescence quenching.

\section{Experimental Section}

General. The IR spectra were recorded on a Varian Excalibur 3100 FT-IR instrument using the attenuated total internal reflection technique (ZnSe crystal). The ${ }^{1} \mathrm{H}$ NMR spectra in $\mathrm{CDCl}_{3}$ and $\mathrm{DMSO}-d_{6}$ were recorded on a Varian Unity 300 spectrometer (300 MHz) and on integrated analytical LC-SPE-NMR-MS system Bruker Avance-600 (600 MHz for ${ }^{1} \mathrm{H}, 120 \mathrm{MHz}$ for $\left.{ }^{13} \mathrm{C}\right)$, the signals were referred with respect to the signals of residual protons of deutero-solvents (7.24 and $2.50 \mathrm{ppm}), \delta$ values were measured with precision $0.01 \mathrm{ppm}$. Mass spectra were recorded on a Shimadzu GCeMSQP2010SE instrument with direct sample entry into the ion source (EI, $70 \mathrm{eV})$. The electronic absorption spectra were recorded on a Varian Cary 100 spectrophotometer. 
The irradiation of solutions with filtered light of a high pressure $\mathrm{Hg}$ lamp was performed on a Newport apparatus supplied with a set of interferential light filters. Emission spectra were recorded on a Varian Cary Eclipse spectrofluorimeter. Toluene of the spectroscopic grade (Aldrich) was used to prepare solutions. Melting points were determined on a PTP (M) instrument.

1-(1-Methylnaphtho[2,1-b]furan-2-yl)ethanone (2). A solution of 1-methylnaphtho[2,1-b]furan (11 mmol, 2.0 g) and $\mathrm{AcCl}\left(14 \mathrm{mmol}, 1.0 \mathrm{~mL}\right.$ ) in $18 \mathrm{~mL}$ of dry benzene was added dropwise with stirring to a solution of $\mathrm{SnCl}_{4}$ (14 mmol, $3.7 \mathrm{~g}$ ) in $22 \mathrm{~mL}$ of dry benzene at $0{ }^{\circ} \mathrm{C}$. The reaction mixture was stirred for $2 \mathrm{~h}$ at ambient temperature and then $10 \%$ aqueous $\mathrm{HCl}(50 \mathrm{~mL})$ was added. The precipitate of 2 was filtered, dried and recrystallized from $n$-BuOH. Yield $68 \%(1.7 \mathrm{~g})$, yellow solid, $\mathrm{mp} 152-153^{\circ} \mathrm{C}$. IR $\left(\mathrm{v}, \mathrm{cm}^{-1}\right): 1665$ (C=O). ${ }^{1} \mathrm{H} N M R$ $\left(300 \mathrm{MHz} \mathrm{CDCl}_{3}\right): \delta 2.67(\mathrm{~s}, 3 \mathrm{H}, \mathrm{Me}), 3.06(\mathrm{~s}, 3 \mathrm{H}, \mathrm{Me}), 7.52-7.69(\mathrm{~m}, 3 \mathrm{H}$, arom. H), $7.89(\mathrm{~d}, 1 \mathrm{H}, \mathrm{arom} . \mathrm{H}, J 9.0$ $\mathrm{Hz}), 7.98(\mathrm{~d}, 1 \mathrm{H}$, arom. $\mathrm{H}, J 8.1 \mathrm{~Hz}), 8.47(\mathrm{~d}, 1 \mathrm{H}$, arom. $\mathrm{H}, J 8.1 \mathrm{~Hz})$. Anal. Calcd (\%) for $\mathrm{C}_{15} \mathrm{H}_{12} \mathrm{O}_{2}: \mathrm{C}, 80.34 ; \mathrm{H}$, 5.39. Found: $\mathrm{C}, 80.47 ; \mathrm{H}, 5.23$.

1-Methylnaphtho[2,1-b]furan-2-carbaldehyde (3). A solution of 1-methylnaphtho[2,1-b]furan (11 mmol, 2.0 $\mathrm{g})$ in $3 \mathrm{~mL}$ of DMF was added dropwise within $0.5 \mathrm{~h}$ with stirring at $0{ }^{\circ} \mathrm{C}$ to the Vilsmeier reagent obtained from DMF $(2 \mathrm{~mL})$ and $\mathrm{POCl}_{3}(2 \mathrm{~mL})$. The reaction mixture was left for $1 \mathrm{~h}$ at ambient temperature and poured into ice $/ \mathrm{H}_{2} \mathrm{O}(700 \mathrm{~mL})$. Gradually, a precipitate of 3 formed as a yellowish cotton. After $30 \mathrm{~h}$ the precipitate was filtered, washed with water, dried and recrystallized from EtOH. Yield 95\% (2.2 g), colourless needles, mp 153$154{ }^{\circ} \mathrm{C}$ [lit. ${ }^{21} 153-154{ }^{\circ} \mathrm{C}$ ]. IR (, $\left.\mathrm{cm}^{-1}\right): 1650$ (C=O). ${ }^{1} \mathrm{H}$ NMR (300 MHz, CDCl $)$ : $\delta 3.01$ (s, 3H, Me), 7.54-7.71 (m, $3 \mathrm{H}$, arom. H), $7.93(\mathrm{~d}, 1 \mathrm{H}$, arom. $\mathrm{H}, J 9.0 \mathrm{~Hz}), 7.99(\mathrm{~d}, 1 \mathrm{H}$, arom. $\mathrm{H}, J 8.1 \mathrm{~Hz}), 8.41(\mathrm{~d}, 1 \mathrm{H}$, arom. $\mathrm{H}, J 8.1 \mathrm{~Hz})$, 10.08 (s, $1 \mathrm{H}$, arom. $\mathrm{H}$ ). Anal. Calcd (\%) for $\mathrm{C}_{14} \mathrm{H}_{10} \mathrm{O}_{2}$ : C, 79.98; $\mathrm{H}, 4.79$. Found: $\mathrm{C}, 80.07 ; \mathrm{H}, 4.66$.

1-(Naphtho[2,1-b]furan-2-yl)ethanone (6). Obtained by a known method. ${ }^{22}$ Yield 82\%, beige plates, mp 113$114{ }^{\circ} \mathrm{C}$ [lit. $\left.{ }^{22} 108-110{ }^{\circ} \mathrm{C}\right]$. IR $\left(\mathrm{v}, \mathrm{cm}^{-1}\right): 1671$ (C=O). Anal. Calcd (\%) for $\mathrm{C}_{14} \mathrm{H}_{10} \mathrm{O}_{2}$ : C, 79.98; H, 4.79. Found: C, $79.82 ; \mathrm{H}, 4.98$.

2-Ethylnaphtho[2,1-b]furan (7). Obtained by a known method. ${ }^{16}$ Yield 80\%, viscous oil, bp $186{ }^{\circ} \mathrm{C} / 16 \mathrm{~mm}\left[\right.$ lit. ${ }^{16}$ $\left.180-185^{\circ} \mathrm{C} / 15 \mathrm{~mm}^{\circ} \mathrm{C}\right]$.

2-Ethylnaphtho[2,1-b]furan-5-carbaldehyde (8). A solution of 2-ethylnaphtho[2,1-b]furan (18 mmol, $4.0 \mathrm{~g})$ in $4 \mathrm{~mL}$ of DMF was added dropwise with stirring to the Vilsmeier reagent obtained from DMF $(4 \mathrm{~mL})$ and $\mathrm{POCl} 3$ $(4 \mathrm{~mL})$. The reaction mixture was stirred for $8 \mathrm{~h}$ at $90^{\circ} \mathrm{C}$, poured into ice/ $\mathrm{H}_{2} \mathrm{O}(400 \mathrm{~mL})$ and left for $16 \mathrm{~h}$. The precipitate of 8 was filtered, purified by $\mathrm{Al}_{2} \mathrm{O}_{3}$ column chromatography $\left(\mathrm{CH}_{2} \mathrm{Cl}_{2}\right)$ and recrystallized from hexane - i-PrOH (10:1) mixture. Yield 81\% (3.7 g), colorless solid, mp 83-84 ${ }^{\circ} \mathrm{C}$. IR $\left(\mathrm{v}, \mathrm{cm}^{-1}\right): 1652(\mathrm{C}=0)$. ${ }^{1} \mathrm{H} N M R(600$ $\mathrm{MHz}_{1} \mathrm{CDCl}_{3}$ ): $\delta 1.42(\mathrm{t}, 3 \mathrm{H}, \mathrm{Me}, J 7.6 \mathrm{~Hz}), 2.94\left(\mathrm{qd}, 2 \mathrm{H}, \mathrm{CH}_{2}, J_{1} 7.6 \mathrm{~Hz}, J_{2} 1.0 \mathrm{~Hz}\right), 6.94(\mathrm{t}, 1 \mathrm{H}$, furan $\mathrm{CH}, J 1.0 \mathrm{~Hz}$ ), 7.62-7.65 (m, 2H, arom. $\mathrm{CH}), 8.08(\mathrm{~d}, 1 \mathrm{H}$, arom. $\mathrm{CH}, J 1 \mathrm{~Hz}), 8.12-8.14(\mathrm{~m}, 1 \mathrm{H}$, arom. $\mathrm{CH}), 9.32-9.35(\mathrm{~m}, 1 \mathrm{H}$, arom. $\mathrm{CH}) 10.37$ (s, $1 \mathrm{H}, \mathrm{CH}$ ). Anal. Calcd (\%) for $\mathrm{C}_{15} \mathrm{H}_{12} \mathrm{O}_{2}$ : C, 80.34; $\mathrm{H}, 5.39$. Found: $\mathrm{C}, 80.41 ; \mathrm{H}, 5.44$.

1-(2-Ethylnaphtho[2,1-b]furan-5-yl)ethanone (10). A solution containing 2-ethylnaphtho[2,1- $b$ ]furan (5 mmol, $1 \mathrm{~mL}$ ) and $\mathrm{AcCl}(5 \mathrm{mmol})$ in anhydrous $\mathrm{MeNO}_{2}(5 \mathrm{~mL})$ was added dropwise with stirring at $0{ }^{\circ} \mathrm{C}$ to a solution containing $\mathrm{SnCl}_{4}(5 \mathrm{mmol})$ in anhydrous $\mathrm{MeNO}_{2}(5 \mathrm{~mL})$. The reaction mixture was stirred for $20 \mathrm{~h}$ and then $2 \%$ aqueous $\mathrm{HCl}(150 \mathrm{~mL})$ was added. The organic layer was then washed with aqueous $\mathrm{HCl}(2 \%, 150 \mathrm{~mL}) \mathrm{and}$ water $(150 \mathrm{~mL})$. Solvent was removed on a rotary evaporator, to afford an oil which was purified by silica gel column chromatography $\left(\mathrm{CH}_{2} \mathrm{Cl}_{2}\right)$ and recrystallized from MeCN. Yield 53\%, colorless solid, $\mathrm{mp} 77-78{ }^{\circ} \mathrm{C}$. IR ( $\mathrm{v}$, $\left.\mathrm{cm}^{-1}\right): 1652(\mathrm{C}=\mathrm{O}) .{ }^{1} \mathrm{H} N M R\left(300 \mathrm{MHz}, \mathrm{CDCl}_{3}\right): \delta 1.40(\mathrm{t}, 3 \mathrm{H}, \mathrm{Me}, J 7.6 \mathrm{~Hz}), 2.76(\mathrm{~s}, 3 \mathrm{H}, \mathrm{Me}), 2.91\left(\mathrm{qd}, 2 \mathrm{H}, \mathrm{CH}_{2}, J_{1}\right.$ $\left.7.6 \mathrm{~Hz}, J_{2} 1.0 \mathrm{~Hz}\right), 6.88(\mathrm{~m}, 1 \mathrm{H}$, furan $\mathrm{H}, J 1.0 \mathrm{~Hz}), 7.54-7.58(\mathrm{~m}, 2 \mathrm{H}$, arom. H), 8.06-8.09 (m, H, arom. H), $8.10(\mathrm{~d}$, $1 \mathrm{H}$, arom. $\mathrm{H}, \mathrm{J} 0.8 \mathrm{~Hz}), 8.94-8.96\left(\mathrm{~m}, 1 \mathrm{H}\right.$, arom. H). ${ }^{13} \mathrm{C} \mathrm{NMR}\left(600 \mathrm{MHz}, \mathrm{CDCl}_{3}\right): \delta 200.63,163.84,149.78$, 
$130.69,128.72,127.79,127.58,127.28$ 126.40, 126.22, 123.59, 115.53, 100.82, 29.69, 22.09, 11.89. EIMS, 70 $\mathrm{eV}, \mathrm{m} / \mathrm{z}: 238$ [M] . Anal. Calcd (\%) for $\mathrm{C}_{16} \mathrm{H}_{14} \mathrm{O}_{2}: \mathrm{C}, 80.65 ; \mathrm{H}, 6.02$. Found: $\mathrm{C}, 80.49 ; \mathrm{H}, 6.18$.

General procedure for the synthesis of fulgides $4 Z, 5 E, 11 E, 13 E, 14 Z$ and compound 12 . A solution of diethyl isopropylidenesuccinate $(5.1 \mathrm{mmol}, 1.1 \mathrm{~g}$ ) and the corresponding carbonyl compound 2, 3, 6, 8 or 10 (5.0 $\mathrm{mmol}$ ) in $15 \mathrm{~mL}$ of THF was added dropwise with stirring to a suspension of $\mathrm{NaH}(7.3 \mathrm{mmol}, 0.29 \mathrm{~g}, 85 \%$ dispersion in paraffin) in $2.5 \mathrm{~mL}$ of THF at ambient temperature. After addition of 1-2 drops of $\mathrm{MeOH}, \mathrm{a}$ characteristic yellow or red color appeared and the evolution of hydrogen began. The reaction mixture was left until hydrogen evolution ceased and then was stirred for $2.5 \mathrm{~h}$ at ambient temperature. The solvent was removed on a rotary evaporator. The residue was dissolved in water $(150-200 \mathrm{~mL})$ and the solution was filtered. The transparent aqueous solution was acidified with $10 \%$ aqueous $\mathrm{HCl}$ up to $\mathrm{pH} 1$. The separated oil of monoethyl ether $\mathbf{M}$ was extracted with $\mathrm{Et}_{2} \mathrm{O}(3 \times 15 \mathrm{~mL})$. $\mathrm{Et}_{2} \mathrm{O}$ was removed on a rotary evaporator. The residue was dissolved was dissolved in $30 \mathrm{~mL}$ of $10 \% \mathrm{KOH}$ in $\mathrm{MeOH}$ and refluxed on water bath for $8 \mathrm{~h}$. The $\mathrm{MeOH}$ was removed on a rotary evaporator. The residue was dissolved in water $(250 \mathrm{~mL})$. The solution was filtered, acidified with $10 \%$ aqueous $\mathrm{HCl}$ up to $\mathrm{pH} 1$. The precipitate of fulgenic acid $\mathbf{F}$ was filtered, dried and dissolved in two-three-fold excess (by weight) of $(\mathrm{EtCO})_{2} \mathrm{O}$. The obtained precipitate of fulgide was filtered off, rinsed with $\mathrm{MeOH}(5 \mathrm{~mL})$, dried and recrystallized.

(Z)-3-(1-(1-Methylnaphtho[2,1-b]furan-2-yl)ethylidene)-4-(propan-2-ylidene)dihydrofuran-2,5-dione

(4Z).

Yield 10\%, orange solid, $\mathrm{mp} 199-200{ }^{\circ} \mathrm{C}$. IR $\left(\mathrm{v}, \mathrm{cm}^{-1}\right): 1801,1762(\mathrm{C}=0) .{ }^{1} \mathrm{H} \mathrm{NMR}\left(300 \mathrm{MHz}, \mathrm{CDCl}_{3}\right): \delta 2.05(\mathrm{~s}, 3 \mathrm{H}$, $\mathrm{Me}), 2.39(\mathrm{~s}, 3 \mathrm{H}, \mathrm{Me}), 2.50(\mathrm{~s}, 3 \mathrm{H}, \mathrm{Me}), 2.64(\mathrm{~s}, 3 \mathrm{H}, \mathrm{Me}), 7.50-7.54(\mathrm{~m}, 1 \mathrm{H}$, arom. H), 7.60 (d, 1H, arom. H, J 8.9 $\mathrm{Hz})$, 7.62-7.65 (m, $1 \mathrm{H}$, arom. $\mathrm{H}), 7.81(\mathrm{~d}, 1 \mathrm{H}$, arom. $\mathrm{H}, \mathrm{J} 8.9 \mathrm{~Hz}), 7.95-7.98(\mathrm{~m}, 1 \mathrm{H}$, arom. $\mathrm{H}), 8.47-8.49(\mathrm{~m}, 1 \mathrm{H}$, arom. H). ${ }^{13} \mathrm{C} \mathrm{NMR}\left(600 \mathrm{MHz}, \mathrm{CDCl}_{3}\right): \delta 163.4,160.2,154.8,153.3,148.4,138.5,130.8,129.2,129.1,128.5$, 127.0, 126.9, 126.5, 124.7, 123.3, 123.2, 121.8, 120.7, 112.2, 27.0, 22.9, 22.6, 14.5. EIMS, 70 eV, $\mathrm{m} / \mathrm{z}: 346$ [M] . Anal. Calcd (\%) for $\mathrm{C}_{22} \mathrm{H}_{18} \mathrm{O}_{4}$ : C, 76.29; $\mathrm{H}, 5.24$. Found: C, 76.39; $\mathrm{H}, 5.15$.

(E)-3-((1-Methylnaphtho[2,1-b]furan-2-yl)methylene)-4-(propan-2-ylidene)dihydrofuran-2,5-dione (5E). Yield $29 \%$, orange solid, $\mathrm{mp} 193-194{ }^{\circ} \mathrm{C}$. IR $\left(\mathrm{v}, \mathrm{cm}^{-1}\right): 1802,1788,1749(\mathrm{C}=0) .{ }^{1} \mathrm{H} \mathrm{NMR}\left(300 \mathrm{MHz}, \mathrm{CDCl}_{3}\right): \delta 1.95(\mathrm{~s}$, $3 \mathrm{H}, \mathrm{Me}), 2.51$ (s, 3H, Me), 2.77 (s, 3H, Me), 7.51-7.72 (m, 4H, arom. H, CH), 7.84 (d, 1H, arom. H, J 9.0 Hz), 7.98 (d, $1 \mathrm{H}$, arom. $\mathrm{H}, J 8.1 \mathrm{~Hz}), 8.40$ (d, $1 \mathrm{H}$, arom. $\mathrm{H}, \mathrm{J} 8.1 \mathrm{~Hz}) .{ }^{13} \mathrm{C} \mathrm{NMR}\left(600 \mathrm{MHz}, \mathrm{CDCl}_{3}\right): \delta 165.8,162.9,159.8$, $153.9,146.8,130.9,129.5,129.4,128.7,127.5,127.4,125.2,123.2,122.8,120.7,119.8,119.7,111.7,26.9$, 20.3, 12.3. EIMS, 70 eV, m/z: 332 [M] ${ }^{+}$. Anal. Calcd (\%) for $\mathrm{C}_{21} \mathrm{H}_{16} \mathrm{O}_{4}$ : C, 75.89; H, 4.85. Found: C, 76.01; $\mathrm{H}, 5.01$. (Z)-3-((1-Methylnaphtho[2,1-b]furan-2-yl)methylene)-4-(propan-2-ylidene)dihydrofuran-2,5-dione (5Z). A solution of fulgide $5 E(0.09 \mathrm{mmol}, 0.03 \mathrm{~g})$ in $3 \mathrm{~mL}$ of benzene was irradiated with sunlight in a Pyrex test tube. During the slow evaporation of the solution a precipitate of pure $\mathbf{5 Z}$ was formed. Thus obtained crystals were transferred to a filter and rinsed with $\mathrm{MeOH}$. Yield $90 \%(0.027 \mathrm{~g})$, orange needles, $\mathrm{mp} 247-248{ }^{\circ} \mathrm{C} . \mathrm{IR}\left(\mathrm{V}, \mathrm{cm}^{-1}\right)$ : 1804, 1757 (C=O). ${ }^{1} \mathrm{H}$ NMR (300 MHz, CDCl 3 ): $\delta 2.40$ (s, 3H, Me), $2.58(\mathrm{~s}, 3 \mathrm{H}, \mathrm{Me}), 2.73(\mathrm{~s}, 3 \mathrm{H}, \mathrm{Me}), 7.27(\mathrm{~s}, 1 \mathrm{H}$, $\mathrm{CH}), 7.51(\mathrm{t}, 1 \mathrm{H}$, arom. $\mathrm{H}, J 7.5 \mathrm{~Hz}), 7.62(\mathrm{t}, 1 \mathrm{H}$, arom. $\mathrm{H}, J 7.6 \mathrm{~Hz}), 7.66(\mathrm{~d}, 1 \mathrm{H}$, arom. $\mathrm{H}, J 8.9 \mathrm{~Hz}), 7.83(\mathrm{~d}, 1 \mathrm{H}$, arom. $\mathrm{H}, J 8.9 \mathrm{~Hz}), 7.95(\mathrm{~d}, 1 \mathrm{H}$, arom. $\mathrm{H}, J 8.1 \mathrm{~Hz}), 8.38(\mathrm{~d}, 1 \mathrm{H}$, arom. $\mathrm{H}, J 8.3 \mathrm{~Hz}) .{ }^{13} \mathrm{C} \mathrm{NMR}(600 \mathrm{MHz}, \mathrm{CDCl}): \delta$ $163.4,161.2,156.3,154.4,146.9,130.9,129.6,129.5,128.7,127.2,127.2,124.9,123.5,123.2,122.8,120.8$, 119.5, 112.7, 25.8, 24.9, 13.4. EIMS, $70 \mathrm{eV}, \mathrm{m} / \mathrm{z}: 332[\mathrm{M}]^{+}$. Anal. Calcd (\%) for $\mathrm{C}_{21} \mathrm{H}_{16} \mathrm{O}_{4}: \mathrm{C}, 75.89 ; \mathrm{H}, 4.85$. Found: C, 76.00; $\mathrm{H}, 4.69$.

(E)-3-(1-(Naphtho[2,1-b]furan-2-yl)ethylidene)-4-(propan-2-ylidene)dihydrofuran-2,5-dione (11E). Yield 19\%, orange solid, $\mathrm{mp} 152-153{ }^{\circ} \mathrm{C}$. IR $\left(\mathrm{v}, \mathrm{cm}^{-1}\right): 1799,1744(\mathrm{C}=0) .{ }^{1} \mathrm{H} \mathrm{NMR}\left(300 \mathrm{MHz}, \mathrm{CDCl}_{3}\right): \delta 1.58(\mathrm{~s}, 3 \mathrm{H}, \mathrm{Me}), 2.42$ $(\mathrm{s}, 3 \mathrm{H}, \mathrm{Me}), 2.80(\mathrm{~s}, 3 \mathrm{H}, \mathrm{Me}), 7.52-7.56(\mathrm{~m}, 2 \mathrm{H}$, arom. $\mathrm{H}), 7.60(\mathrm{~s}, 1 \mathrm{H}$, furan $\mathrm{H}), 7.63-7.67(\mathrm{~m}, 1 \mathrm{H}$, arom. $\mathrm{H}), 7.82$ (d, $1 \mathrm{H}$, arom. $\mathrm{H}, J 8.9 \mathrm{~Hz}), 7.96(\mathrm{~d}, 1 \mathrm{H}$, arom. $\mathrm{H}, J 8.2 \mathrm{~Hz}), 8.13(\mathrm{~d}, 1 \mathrm{H}$, arom. $\mathrm{H}, J 8.2 \mathrm{~Hz}) .{ }^{13} \mathrm{C} \mathrm{NMR}(600 \mathrm{MHz}$, $\left.\mathrm{CDCl}_{3}\right): \delta 163.8,163,0$ 156.6, 153.9, 153.4, 137.9, 130.5, 129.1, 128.1, 127.4, 127.3, 125.4, 123.7, 123.3, 121.1, 
119.6, 111.8, 110.9, 25.3, 22.7, 18.6. EIMS, 70 eV, m/z (\%): 332 (100) [M+], 304 (21), 289 (25), 259 (42), 245 (31), 144 (20). Anal. Calcd (\%) for $\mathrm{C}_{21} \mathrm{H}_{16} \mathrm{O}_{4}$ : C, 75.89; $\mathrm{H}, 4.85$. Found: $\mathrm{C}, 76.02 ; \mathrm{H}, 4.96$.

(Z)-3-(1-(Naphtho[2,1-b]furan-2-yl)ethylidene)-4-(propan-2-ylidene)dihydrofuran-2,5-dione (11Z). Obtained similarly to $5 Z$ while irradiation and slow evaporation of the solution of $11 E(0.04 \mathrm{mmol}, 0.14 \mathrm{~g})$ in $2 \mathrm{~mL}$ of acetonitrile. Yield $72 \%$, orange solid, $\mathrm{mp} 181-182{ }^{\circ} \mathrm{C}$. IR $\left(\mathrm{v}, \mathrm{cm}^{-1}\right): 1801,1748(\mathrm{C}=0) .{ }^{1} \mathrm{H} \mathrm{NMR}\left(300 \mathrm{MHz}^{\mathrm{CDCl}} 3\right)$ : $\delta 2.01(\mathrm{~s}, 3 \mathrm{H}, \mathrm{Me}), 2.40(\mathrm{~s}, 3 \mathrm{H}, \mathrm{Me}), 2.45$ (s, 3H, Me), $7.51(\mathrm{t}, 1 \mathrm{H}$, arom. $\mathrm{H}, J 7.5 \mathrm{~Hz}), 7.60-7.63(\mathrm{~m}, 2 \mathrm{H}$, arom. H), $7.80(\mathrm{~d}, 1 \mathrm{H}$, arom. H, J $9.0 \mathrm{~Hz}), 7.92(\mathrm{~d}, 1 \mathrm{H}$, arom. H, J $8.1 \mathrm{~Hz}), 8.22(\mathrm{~d}, 1 \mathrm{H}$, arom. H, J $8.1 \mathrm{~Hz}), 8.38(\mathrm{~s}, 1 \mathrm{H}$, furan H). ${ }^{13} \mathrm{C}$ NMR $\left(600 \mathrm{MHz}, \mathrm{CDCl}_{3}\right): \delta 163.4,161.3,154.6,153.3,151.0,139.0,130.4,128.9,128.5,127.9,127.1$, 125.2, 124.0, 123.7, 122.3, 119.9, 114.7, 112.0, 27.0, 22.5, 22.1. EIMS, 70 eV, m/z: 332 [M+'. Anal. Calcd (\%) for $\mathrm{C}_{21} \mathrm{H}_{16} \mathrm{O}_{4}: \mathrm{C}, 75.89 ; \mathrm{H}, 4.85$. Found: $\mathrm{C}, 76.01 ; \mathrm{H}, 5.01$.

(E)-3-((E)-4-(Naphtho[2,1-b]furan-2-yl)pent-3-en-2-ylidene)dihydrofuran-2,5-dione (12). Yield $11 \%$ (0.2 g), yellow cotton, $\mathrm{mp} 241-242{ }^{\circ} \mathrm{C}$. IR $\left(\mathrm{v}, \mathrm{cm}^{-1}\right): 1823,1746(\mathrm{C}=0) .{ }^{1} \mathrm{H} \mathrm{NMR}\left(300 \mathrm{MHz}, \mathrm{CDCl}_{3}\right): \delta 2.22(\mathrm{~s}, 3 \mathrm{H}, \mathrm{Me})$, $2.29(\mathrm{~s}, 3 \mathrm{H}, \mathrm{Me}), 3.57\left(\mathrm{~s}, 2 \mathrm{H}, \mathrm{CH}_{2}\right), 7.36(\mathrm{~s}, 1 \mathrm{H}$, arom. $\mathrm{H}), 7.46-7.49(\mathrm{~m}, 1 \mathrm{H}$, arom. $\mathrm{H}), 7.56-7.59(\mathrm{~m}, 1 \mathrm{H}$, arom. $\mathrm{H}), 7.63(\mathrm{~d}, 1 \mathrm{H}$, arom. $\mathrm{H}, J 8.9 \mathrm{~Hz}), 7.74(\mathrm{~d}, 1 \mathrm{H}$, arom. $\mathrm{H}, J 8.9 \mathrm{~Hz}), 7.89(\mathrm{~s}, 1 \mathrm{H}$, arom. H), $7.92(\mathrm{~d}, 1 \mathrm{H}, \mathrm{arom} . \mathrm{H}, J$ $8.2 \mathrm{~Hz}), 8.11(\mathrm{~d}, 1 \mathrm{H}$, arom. $\mathrm{H}, J 8.2 \mathrm{~Hz}) .{ }^{13} \mathrm{C} \mathrm{NMR}\left(600 \mathrm{MHz}_{\mathrm{CDCl}}\right): \delta$ 168.5, 162.9, 156.4, 153.0, 152.0, 132.7, $130.4,128.9,127.6,126.6,126.5,124.8,124.2,123.8,123.3,118.0,112.3,104.7,34.7,22.9,16.3$. EIMS, 70 eV, $\mathrm{m} / \mathrm{z}: 332\left[\mathrm{M}^{+}\right]$. Anal. Calcd (\%) for $\mathrm{C}_{21} \mathrm{H}_{16} \mathrm{O}_{4}: \mathrm{C}, 75.89 ; \mathrm{H}, 4.85$. Found: C, 76.01; $\mathrm{H}, 4.96$.

(E)-3-((2-Ethylnaphtho[2,1-b]furan-5-yl)methylene)-4-(propan-2-ylidene)dihydrofuran-2,5-dione (13E). Yield $42 \%$ (0.7 g), beige solid, mp 184-185 ${ }^{\circ} \mathrm{C} . \mathrm{IR}\left(\mathrm{v}, \mathrm{cm}^{-1}\right): 1815,1766(\mathrm{C}=0) .{ }^{1} \mathrm{H} \mathrm{NMR}\left(300 \mathrm{MHz}, \mathrm{CDCl}_{3}\right): \delta 1.33(\mathrm{~s}, 3 \mathrm{H}$, $\mathrm{Me}$ ), 1.40 (t, 3H, Me, J $7.5 \mathrm{~Hz}$ ), 2.40 (s, 3H, Me), 2.91 (q, 2H, CH,$J 7.5 \mathrm{~Hz}$ ), 6.91 (s, 1H, furan H), $7.48(\mathrm{~s}, 1 \mathrm{H}$, arom. H), $7.56(t, 1 \mathrm{H}$, arom. $\mathrm{H}, J 7.5 \mathrm{~Hz}), 7.63(\mathrm{t}, 1 \mathrm{H}$, arom. $\mathrm{H}, J 7.5 \mathrm{~Hz}), 8.02(\mathrm{~d}, 1 \mathrm{H}$, arom. H, J $8.4 \mathrm{~Hz}), 8.13(\mathrm{~d}$, $1 \mathrm{H}$, arom. $\mathrm{H}, J 8.1 \mathrm{~Hz}), 8.33(\mathrm{~s}, 1 \mathrm{H}, \mathrm{CH}) .{ }^{13} \mathrm{C} \mathrm{NMR}\left(600 \mathrm{MHz}, \mathrm{CDCl}_{3}\right): \delta 165.66,163.24,163.06,158.69,150.35$, $136.13,128.62,127.57,127.43,127.20,126.81,125.67,125.03,124.35,123.03,118.52,112.70,100.88,28.38$, 23.22, 22.08, 11.86. EIMS, $70 \mathrm{eV}, \mathrm{m} / \mathrm{z}$ : $346\left[\mathrm{M}^{+}\right]$. Anal. Calcd (\%) for $\mathrm{C}_{22} \mathrm{H}_{18} \mathrm{O}_{4}: \mathrm{C}, 76.29 ; \mathrm{H}, 5.24$. Found: C, $76.43 ; \mathrm{H}, 5.12$.

(Z)-3-(1-(2-Ethylnaphtho[2,1-b]furan-5-yl)ethylidene)-4-(propan-2-ylidene)dihydrofuran-2,5-dione

(14Z).

Yield 90\% (0.27 g) light brown solid, mp 165-167 ${ }^{\circ} \mathrm{C}$. IR $\left(\mathrm{v}, \mathrm{cm}^{-1}\right): 1809,1767,1755$ (C=0). ${ }^{1} \mathrm{H} \mathrm{NMR} \mathrm{(600} \mathrm{MHz,}$ DMCO-d $)_{6}$ : $\delta 1.40(\mathrm{t}, 3 \mathrm{H}, \mathrm{Me}, J 7.5 \mathrm{~Hz}), 2.24(\mathrm{~s}, 3 \mathrm{H}, \mathrm{Me}), 2.36(\mathrm{~s}, 3 \mathrm{H}, \mathrm{Me}), 2.53(\mathrm{~s}, 3 \mathrm{H}, \mathrm{Me}), 2.90\left(\mathrm{q}, 2 \mathrm{H}, \mathrm{CH}_{2}, J\right.$ $7.5 \mathrm{~Hz}), 6.90(\mathrm{~d}, 1 \mathrm{H}$, furan $\mathrm{H}, J 0.6 \mathrm{~Hz}), 7.26-7.46(\mathrm{~m}, 2 \mathrm{H}$, arom. $\mathrm{H}), 7.53-7.59(\mathrm{~m}, 1 \mathrm{H}$, arom. $\mathrm{H}), 7.71(\mathrm{~d}, 1 \mathrm{H}$, arom. $\mathrm{H}, J 8.4 \mathrm{~Hz}), 8.13$ (d, $1 \mathrm{H}$, arom. $\mathrm{H}, J 8.1 \mathrm{~Hz}) .{ }^{13} \mathrm{C} \mathrm{NMR}\left(600 \mathrm{MHz}, \mathrm{CDCl}_{3}\right): \delta$ 163.2, 161.1, 161.0, 154.83, $154.81,151.5,150.9,134.1,127.7,127.3,126.0,124.8,124.7,124.4,124.3,120.9,110.8,100.4,27.9,27.4$, 22.5, 22.0, 12.1. EIMS, $70 \mathrm{eV}, \mathrm{m} / \mathrm{z}: 360\left[\mathrm{M}^{+}\right]$. Anal. Calcd (\%) for $\mathrm{C}_{23} \mathrm{H}_{20} \mathrm{O}_{4}: \mathrm{C}, 76.65 ; \mathrm{H}, 5.59$. Found: C, 76.51; $\mathrm{H}$, 5.42 .

\section{Acknowledgements}

This work was performed in the scope of the basic part of the State Task of RF in the sphere of scientific activity (Nos. 4.6497.2017/8.9 and 4.5593.2017/6.7) and State Assignment of RSC SSC RAS (no. 01201354239). 


\section{Supplementary Material}

The ${ }^{1} \mathrm{H},{ }^{13} \mathrm{C}$ NMR and IR spectra of new compounds: this material can be found using the link "Supplementary Material" in the journal issue contents page.

\section{References}

1. Yokoyama, Y.; Nakatani, K. Photon-Working Switches; Springer, 2017.

2. Tian, H.; Zhang, J. Photochromic Materials; Wiley-VCH, Weinheim, 2016.

3. Andreasson, J.; Pischel, U. Chem. Soc. Rev. 2015, 44, 1053.

http://dx.doi.org/10.1039/C4CS00342J

4. Bisoyi, H. K.; Li Q. Chem. Rev. 2016, 24, 15089.

https://doi.org/10.1021/acs.chemrev.6b00415

5. Cho, H. J.; Chung, M.; Shim, M. S. J. Ind. Eng. Chem. 2015, 31, 15.

https://doi.org/10.1016/j.jiec.2015.07.016

6. Zhang J., Zou Q., Tian H., Adv. Mater. 2013, 25, 378.

https://doi.org/10.1002/adma.201201521

7. Velema, W. A.; Szymanski, W.; Feringa, B. L. J. Am. Chem. Soc. 2014, 136, 2178.

https://doi.org/10.1021/ja413063e

8. Natali, M.; Giordani, S. Chem. Soc. Rev. 2012, 41, 4010.

https://doi.org/10.1039/C2CS35015G

9. Wang, G.; Zhang, J. J. Photochem. Photobiol. C 2012, 13, 299.

https://doi.org/10.1016/j.jphotochemrev.2012.06.002.003

10. Yokoyama, Y. Chem. Rev. 2000, 100, 1717.

http://dx.doi.org/10.1021/cr980070c

11. Yokoyama, Y.; Kose, M. J. Photochem. Photobiol. A: Chem. 2004, 166, 9.

http://dx.doi.org/10.1016/j.jphotochem.2004.04.023

12. Liang, Y. C.; Dvornikov, A. S.; Rentzepis, P. M. Macromolecules 2002, 35, 9377.

http://dx.doi.org/10.1021/ma020750o

13. Makarova, N. I.; Chernyshev, A. V.; Rybalkin, V. P.; Zmeeva, S. Yu.; Popova, L. L.; Tikhomirova, K. S.;

Metelitsa, A. V.; Dubonosov, A. D.; Bren, V. A.; Minkin, V. I. Arkivoc 2016, (vi), 1.

https://doi.org/10.24820/ark.5550190.p009.806

14. Balenko, S. K.; Makarova, N. I.; Rybalkin, V. P.; Shepelenko, E. N.; Popova, L. L.; Tkachev, V. V.; Aldoshin, S. M.; Metelitsa, A. V.; Bren, V. A.; Minkin, V. I. Russ. Chem. Bull. 2010, 59, 954.

http://dx.doi.org/10.1007/s11172-010-0189-x

15. Yokoyama, Y.; Kose, M. In Organic Photochemistry and Photobiology; Horspool W.; Lenci, F., Eds.; CRC Press: Boca Raton, 2004, pp 1-13.

16. Bisagni, M.; Buu-Hoï, N. P.; Royer, R. J. Chem. Soc. 1955, 3688. http://dx.doi.org/10.1039/JR9550003688

17. Glaze, A.; Harris, S.; Heller, H.; Johncock, W.; Oliver, S.; Strydom, P.; Whittall, J. J. Chem. Soc., Perkin Trans. 1 1985, 957.

http://dx.doi.org/10.1039/P19850000957 
18. Renth, F.; Siewertsen, R.; Strube, F.; Mattay, J.; Temps, F. Phys. Chem. Chem. Phys. 2014, 16, 19556. http://dx.doi.org/10.1039/c4cp01739k

19. Zmeeva, S. Yu.; Rybalkin, V. P.; Popova, L. L.; Tkachev, V. V.; Revinskii, Yu. V.; Tikhomirova, K. S.; Starikov A. G.; Dubonosov, A. D.; Bren, V. A.; Aldoshin, S. M.; Minkin, V. I. Tetrahedron 2016, 72, 5776. https://doi.org/10.1016/i.tet.2016.08.002

20. Siewertsen, R.; Strube, F.; Mattay, J.; Renth, F.; Temps, F. Phys. Chem. Chem. Phys. 2011, 13, 15699. http://dx.doi.org/10.1039/c1cp21320b

21. Giovanninetti, G. ; Garuti, L. ; Chiarini A. ; Gaggi R. Farmaco Sci., 1981, 36, 94.

22. Abd El-Wahab, A. H. F.; Al-Fifi, Z. I. A.; Bedair, A. H.; Ali, F. M.; Halawa, A. H. A.; El-Agrody, A. M. Molecules 2011, 16, 307.

https://doi.org/10.3390/molecules16010307 